\title{
Effects of mild and severe drought stress on the biomass, phenolic compounds production and photochemical activity of Aloe vera (L.) Burm.f.
}

\author{
Ghader HABIBI ${ }^{1 *}$
}

Received June 07, 2018; accepted September 06, 2018.

Delo je prispelo 07. junija 2018, sprejeto 06. septembra 2018.

\begin{abstract}
In this study, the biomass, compatible solutes, PSII functioning and phenolic profiles of Aloe vera (L.) Burm.f. leaves were investigated at different time intervals after drought stress (20, 40 and $80 \%$ of the field capacity). While the impaired ability of leaves for synthesis of assimilates caused growth inhibition in $A$. vera under severe drought stress, we observed that the content of proline, soluble sugars, total phenolic and flavonoids tended to increase in plants treated with mild drought stress. Under mild drought stress, the increased leaf thickness correlated with the higher productivity in terms of leaf biomass and gel production. Also, mild drought stress enhanced photochemical activity in Aloe leaves, and changed the entire quantity of secondary metabolite of vanillic acid produced, which may be considered to obtain better growth and considerable secondary metabolite of the medicinal Aloe plants treated with mild drought stress.
\end{abstract}

Key words: Aloe vera leaves; carotenoids; leaf thickness; photosystem II performance index; vanillic acid; drought stress
IZVLEČEK

\author{
UČINEK BLAGEGA IN MOČNEGA SUŠNEGA \\ STRESA NA BIOMASO, TVORBO FENOLNIH SNOVI \\ IN FOTOKEMIČNO AKTIVNOST VRSTE Aloe vera $(\mathrm{L}$. \\ Burm.f.
}

$\mathrm{V}$ raziskavi so bili preučevani biomasa, osmotiki, delovanje fotosistema II in profil fenolnih snovi v listih vrste Aloe vera $\mathrm{v}$ različnih intervalih po vzpostavitvi sušnega stresa $(20,40$ in $80 \%$ poljske kapacitete). Medtem, ko je bila rast zavrta zaradi zmanjšane fotosintetske sposobnosti listov, je bila pri blagem sušnem stresu povečana vsebnost prolina, topnih sladkorjev, celokupnih fenolov in flavonoidov. Pri blagem sušnem stresu je povečana debelina listov korelirala $\mathrm{z}$ večjo produktivnostjo glede na biomaso in tvorbo gela. Blag sušni stres je povečal fotokemično aktivnost listov in spremenil količino sekundarnega metabolita vanilijske kisline in njenih derivatov. Sklepamo lahko, da blag sušni stres poveča rast in tvorbo sekundarnih metabolitov pri tej zdravilni rastlini.

Ključne besede: Aloe vera listi; karotenoidi; debelina listov; indeks učinkovitosti fotosistema II; vanilijska kislina; sušni stres

\section{INTRODUCTION}

Environmental stresses, such as drought, low or high temperature and excessive salinity have negative influence on the plant, causing changes in its normal growth, development and metabolism (Bohenert et al., 1995; Kranner et al., 2010). Drought stress induces oxidative stress through enhancing the formation of reactive oxygen species (ROS). ROS can react with photosynthetic pigments, lipids, proteins and DNA (Ahmad et al., 2010), leading eventually to lipid peroxidation, membrane damage, inactivation of antioxidant enzymes and cell death (Gill and Tuteja, 2010). However, for the detoxification of excessively produced ROS, plants possess a developed antioxidative defense mechanism. ROS scavenging occurs by a large number of ROS detoxifying enzymes and by antioxidants (Gill and Tuteja, 2010; Mittler et al., 2011).

To survive at drought stress conditions and to achieve maximum drought resistance, plants have developed adaptation strategy, which is associated with physiological traits, e.g., increased osmoprotectant and accumulation of sugars (Kooyers, 2015). In addition, drought avoidance occurs when plants enhance wateruse efficiency (WUE) by decreasing transpiration, or increasing root growth. Generally, CAM plants are the best accommodated to hot and dry climatic conditions,

1 Department of Biology, Payame Noor University (PNU), 19395-3697 Tehran, Iran *corresponding author: gader.habibi@gmail.com 
because they have higher water-use efficiency (WUE) than that of $\mathrm{C}_{3}$ plants (Habibi, 2016). A. vera (L.) Burm. $\mathrm{f}$. is a drought tolerant species that is considered as a constitutive CAM species (Silva et al., 2010). Nevertheless, drought stress can limit A. vera growth and production (Delatorre-herrera et al., 2010; Cousins and Witkowski, 2012). In A.vera, the synthesis of soluble sugars, proline and secondary metabolites are highly affected by water deficit stress (Lucini et al., 2013; Ray et al., 2013).

Phenolic compounds are the most widespread substantial groups of plant secondary metabolites that exhibit antioxidant properties (Quan et al., 2016). Several investigators have reported that the levels of phenolic compounds such as phenolic acids and flavonoids were influenced by drought stress in tobacco and wheat leaves (Ma et al., 2014).These compounds can scavenge ROS (Quan et al., 2016) and prevent lipid peroxidation, protein denaturation and DNA damage (Mittler, 2002; Król et al., 2014). Interestingly, the relationship between water availability and phenolic compounds synthesis is dependent on the plant species, treatments and/or experimental systems. Some studies have shown that environmental stress can cause a decline (Weidner et al., 2009). However, other studies have indicated that stress increases phenolic compounds accumulation (Weidner et al., 2009; Król et al., 2014). Thus, the exact mechanism of phenolic compounds accumulation in response to long and continuous stressor remains unknown.

Aloe vera as a CAM plant and one of the most important medicinal plants grows in warm and dry regions. Several studies have been conducted focusing on $A$. vera adaptation to water deficit stress; however information is lacking on the role of phenolic compounds, compatible solutes as well as photochemical reactions in Aloe vera plants exposed to mild and severe water stress, which may be one of the most important approaches to overcome with water deficit stress. In this study, changes in compatible solutes, PSII functioning and individual phenolic acids in response to mild and severe drought stress in $A$. vera were investigated. We also hypothesized that regulation of water availability may be a promising way to obtain the highest concentrations of secondary metabolite in the medicinal plant.

\section{MATERIALS AND METHODS}

\subsection{Plant material and treatments}

The 15-17 $\mathrm{cm}$ pups (small plants growing from the sides of the mother plant) of Aloe vera (L.) Burm.f. plants were chosen and planted in top of the cylindrical plastic pots (18 cm in diameter and $45 \mathrm{~cm}$ in depth) containing $10 \mathrm{~kg}$ sandy loam soil $(\mathrm{pH} \mathrm{7.3)}$ for five months, and irrigated with distilled water every 10 days to maintain at $80 \%$ field capacity (FC). Plants were grown under day/night temperature of $30-35 / 18-22{ }^{\circ} \mathrm{C}$, relative humidity of $50-55 \%$ and daily photon flux density of about 500-600 $\mu \mathrm{mol} \mathrm{m} \mathrm{m}^{-2} \mathrm{~s}^{-1}$ in an environmentally controlled growth chamber throughout the pre-experimental period. The treatments of drought stress were composed of control ( $80 \%$ FC), mild drought stress (40\% FC) and severe drought stress (20\% FC). Finally, plants were harvested and analyzed in a temporal (on different days after imposition of drought stress) manner.

\subsection{Chlorophyll $a$ fluorescence measurements}

Chlorophyll $a$ fluorescence transients (OJIP transients) were evaluated with a Packet-PEA chlorophyll fluorimeter (Plant Efficiency Analyser, Hansatech Instruments Ltd., King's Lynn, Norfolk, PE 32 1JL, England) in dark-adapted leaves for at least $20 \mathrm{~min}$, using the $J I P$-test to analyse chlorophyll $a$ fluorescence rises. Some groups of measured and calculated parameters using the JIP-test (Strasser et al., 2004) were described in the following section.

- $F_{\mathrm{v}} / F_{\mathrm{m}}$, the maximum PSII photochemical efficiency, namely the maximum quantum yield of primary photochemistry. Where $F_{\mathrm{m}}$ or $F_{\max }$ is maximal chlorophyll fluorescence intensity measured when all photosystem II (PSII) reaction centers are closed, $F_{\mathrm{v}}$ is variable chlorophyll fluorescence $\left(F_{\mathrm{m}}-F_{\mathrm{o}}\right), F_{\mathrm{o}}$ is minimal fluorescence (all PSII RCs are assumed to be open), respectively.

- $\mathrm{PI}_{\mathrm{abs}}$, the performance index that is calculated as: $(\mathrm{RC} / \mathrm{ABS}) \times\left(\varphi_{\mathrm{Po}} /\left(1-\varphi_{\mathrm{Po}}\right)\right) \times\left(\psi_{\mathrm{o}} /\left(1-\psi_{\mathrm{o}}\right)\right)$, where, $\mathrm{RC}$ is for reaction center; $\mathrm{ABS}$ is for absorption flux; $\varphi_{\text {Po }}$ is for maximal quantum yield for primary photochemistry; and $\psi_{\mathrm{o}}$ is for the quantum yield for electron transport

\subsection{Determination of total carotenoids, chlorophyll $a$ and $b$}

The leaf concentration of chlorophyll and carotenoids was analysed according to Lichtenthaler and Wellburn (1983). After centrifugation at $1000 \mathrm{rpm}$ for one minute, supernatants were used for determination of photosynthetic pigments, and the absorbance was read at 400-700 $\mathrm{nm}$ on spectrophotometer. Leaf concentrations of chlorophylls and carotenoids were calculated as: 
Chl a $=15.65$ A666 - 7.340 A653

$\mathrm{Chl} \mathrm{b}=27.05$ A653 - 11.21 A666

Total carotenoids $=1000 \mathrm{~A} 470-2.860 \mathrm{Ca}-129.2$ $\mathrm{Cb} / 245$

\subsection{Estimation of total proline, soluble sugars and starch}

Proline was determined by the method of Bates et al. (1973). Leaf samples from each group were homogenized in $3 \%(\mathrm{w} / \mathrm{v})$ sulphosalycylic acid and the homogenate was centrifuged at $3,000 \mathrm{~g}$ for $20 \mathrm{~min}$. Mixture was boiled for $1 \mathrm{~h}$ in water bath after addition of acid ninhydrin and glacial acetic acid. Reaction was then stopped by ice bath, and then absorbance at $520 \mathrm{~nm}$ was determined. Proline (Sigma) was used for production of a standard curve. For determination of total soluble sugars and starch contents, fresh leaves were extracted in $20 \mathrm{ml}$ of $80 \%(\mathrm{v} / \mathrm{v})$ ethanol at $95^{\circ} \mathrm{C}$ for $1 \mathrm{~h}$. After centrifugation at $10,000 \mathrm{~g}$ for $10 \mathrm{~min}$, starch was determined in the pellet according to Jarvis and Walker (1993). Total soluble sugars were analyzed using anthrone reagent according to Irigoyen et al (1992).

\subsection{Assay of phenylalanine ammonia-lyase (PAL) activity and related metabolites}

To determine PAL activity, formation of cinnamic acid was recorded by spectrophotometry at $290 \mathrm{~nm}$ according to modified method of Zucker (1965). One unit $(\mathrm{U})$ of PAL activity was defined as the amount of the enzyme that produced $1 \mathrm{nmol}$ cinnamic acid per $\mathrm{h}$. Total phenolic content was quantified by the method of Velioglu et al. (1998). Gallic acid was used for constructing the standard curve. Results were expressed as mg gallic acid (GA) per gram of the fresh mass. Total flavonoid content was assessed using the method adapted by Meda et al. (2005). Briefly, $5 \mathrm{ml}$ of $2 \%$ aluminium chloride $\left(\mathrm{AlCl}_{3}\right)$ in methanol was mixed with the same volume of leaf extracts $\left(0.02 \mathrm{mg} \mathrm{ml}^{-1}\right)$. Absorption readings at $415 \mathrm{~nm}$ were taken after 10 minutes against a blank sample without $\mathrm{AlCl}_{3}$. The total flavonoid content was calculated using a standard curve of quercetin and expressed as $\mathrm{mg}$ quercetin equivalent (QE)/100 g extract. Anthocyanin content was estimated according to the method of Krizek et al. (1993) using HCl-methanol solvent (1: 99, v: v), and the amount of anthocyanin was ranked from the absorbance at $550 \mathrm{~nm}$.

\subsection{HPLC analysis}

For the sample preparation and calibration curves, the powdered leaves $(0.5 \mathrm{~g})$ were extracted with methanol $(5 \mathrm{ml})$ in a shaking incubator for 8 hours at room temperature. The supernatant was centrifuged at $3000 \mathrm{~g}$ for 3 minutes, and then filtered prior to HPLC analysis. For the calibration curve, the stock solutions of the identified phenolic compounds (chlorogenic acid, syrginic acid, gallic acid, rosmarinic acid, vanillic acid and luteolin) were equipped with methanol to obtain a 1 $\mathrm{mg} \mathrm{ml}{ }^{-1}$ concentration, and the calibration curves for standard samples were fabricated by plotting the peak area of the identified phenolic compounds against their concentrations through dilution of each stock solution in methanol to six concentrations $(0.78 \mathrm{ppm}, 1.58 \mathrm{ppm}$, $3.12 \mathrm{ppm}, 6.25 \mathrm{ppm}$ and $25 \mathrm{ppm})$. Vanillic acids were identified at $245 \mathrm{~nm}$, gallic and syrginic acids at 275 $\mathrm{nm}$, chlorogenic and rosmarinic acids at $320 \mathrm{~nm}$ and luteolin at $350 \mathrm{~nm}$. The correlation coefficients $\left(\mathrm{r}^{2}\right)$ of all phenolic standards were higher than 0.993 .

The HPLC analysis was done using a Knauer liquid chromatography apparatus Shimadzu HPLC instrument (a 1000 Smartline Pump, a 5000 Smartline Manager Solvent Organizer and a 2800 Smartline Photodiode Array Detector). Separation achieve on a $25 \mathrm{~cm} \times 4.6$ $\mathrm{mm}$ with a pre-column, Eurospher 100-5 C18 analytical column provided by Knauer (Berlin, Germany). Data acquisition and integration perform with EZchrom Elite software. A $20 \mu \mathrm{l}$ sample of the methanol extract of Aloe vera leaves was injected into an HPLC column through a 3900 Smartline Auto-sampler injector equipped with a $100 \mu \mathrm{l}$ loop. Separation was performed using $0.02 \%$ trifluoroacetic acid in water (elution A) and methanol (elution D). The total running time was 55 minutes at a flow rate of $0.5 \mathrm{ml} \mathrm{min} \mathrm{m}^{-1}$, and the oven temperature was $20^{\circ} \mathrm{C}$.

\subsection{DPPH assay}

The antiradical activity was estimated by using the method described by Yen and Chen (1995). Briefly, the mixture of methanolic extract and DPPH (2, 2-diphenyl1-picrylhydrazyl) solution was left in the dark at room temperature for $20 \mathrm{~min}$, and then absorbance was recorded at a wavelength of $517 \mathrm{~mm}$.

\subsection{Statistical analysis}

Experiments were performed in complete randomized block design (RBD) with 4 replications. Statistical analysis was carried out using sigma stat (3.5) with Tukey test $(\mathrm{P}<0.05)$. Correlation analysis using Spearman Rank Order Correlation in sigma stat (3.5) was applied to determine the relationship between parameters. Chlorophyll fluorescence data were analyzed and conducted using the PEA Plus V1.10 software. 


\section{RESULTS AND DISCUSSION}

\subsection{Biomass and gel production and water relations under mild and severe water stress}

Drought is one of the major abiotic stresses affecting plant growth worldwide (Wu et al., 2018). However Aloe vera is a promising crop for arid zones, with high yield of leaf biomass and gel production under mild water stress conditions (Silva et al., 2010), but it has been demonstrated that severe drought stress decreases leaf yield and growth of Aloe vera (Silva et al., 2014; Hazrati et al., 2017). This is confirmed by the present study showing that the production of leaves biomass and gel was not influenced by mild drought stress and only the severe drought stress caused significant biomass reduction (Table 1). In plants treated with drought for 180 days, leaf thickness tended to increase under mild drought stress, while leaf thickness and relative water content (RWC) were reduced under severe drought stress. In these conditions, A. vera exhibited morphologic plasticity to adapt to water deficit. Indeed, succulent plants can exhibit plasticity in their photosynthesis depending on the presence of thick leaves (Habibi and Ajori, 2015, Habibi, 2016).

Table 1: Effects of mild and severe drought stress on the leaf biomass $\left(\mathrm{g} \mathrm{leaf}^{-1}\right)$, relative water content (RWC, \%) and leaf thickness $(\mathrm{mm})$ of Aloe vera. Measurements were performed $180 \mathrm{~d}$ after drought treatments. Data of each row within each defined plant part indicated by the same letter are not significantly different $(p<0.05$, Tukey test). Values are the mean $\pm \mathrm{SD}(\mathrm{n}=8)$.

\begin{tabular}{llll}
\hline & Control & Mild drought stress & Severe drought stress \\
\hline Fresh leaf biomass & $550 \pm 29^{\mathrm{a}}$ & $526 \pm 35^{\mathrm{a}}$ & $352 \pm 38^{\mathrm{b}}$ \\
Photosynthetic tissue & $185 \pm 21^{\mathrm{a}}$ & $197 \pm 24^{\mathrm{a}}$ & $145 \pm 28^{\mathrm{b}}$ \\
Gel & $365 \pm 17^{\mathrm{a}}$ & $329 \pm 29^{\mathrm{a}}$ & $207 \pm 23^{\mathrm{b}}$ \\
\hline Dry leaf biomass & $45 \pm 6.2^{\mathrm{a}}$ & $44 \pm 3.7^{\mathrm{a}}$ & $32 \pm 3.2^{\mathrm{b}}$ \\
Photosynthetic tissue & $19 \pm 4.4^{\mathrm{a}}$ & $21 \pm 4.0^{\mathrm{a}}$ & $15 \pm 3.3^{\mathrm{a}}$ \\
Gel & $26 \pm 2.3^{\mathrm{a}}$ & $23 \pm 3.6^{\mathrm{a}}$ & $17 \pm 2.9^{\mathrm{b}}$ \\
\hline RWC & $88 \pm 3.7^{\mathrm{a}}$ & $84 \pm 4.5^{\mathrm{a}}$ & $71 \pm 2.2^{\mathrm{b}}$ \\
\hline leaf thickness $(\mathbf{m m})$ & $13.2 \pm 1.14^{\mathrm{ab}}$ & $16.0 \pm 2.23^{\mathrm{a}}$ & $10.4 \pm 1.07^{\mathrm{b}}$ \\
\hline
\end{tabular}

\subsection{Possible importance of compatible solutes in the responses of $A$. vera plants to mild drought stress}

After 120 and 180 days of exposure, the content of proline and soluble sugars was increased by mild drought stress. The content of starch, however, was not affected in plants treated for 60,120 and 180 days with both mild and severe drought stress (Fig. 1). CAM plants ability to maintain growth under drought stress is based on the efficient synthesis of sugars, polysaccharides and other osmolytes, such as proline and glycine betaine (Delatorre-herrera et al., 2010; Salinas et al., 2016) in order to adaptation to water deficit. Similarly, our results showed that mild drought stress significantly increased proline and soluble sugars contents, which might have a scavenger function and act as an osmolyte (Sankar et al., 2007; Salinas et al., 2016). Nevertheless, under the severe drought stress, the content of proline and soluble sugars did not continue to increase probably due to source limitations. In this study, the maintenance of dry matter production under mild drought stress may have contributed to the enhanced levels of compatible solutes during the experiment. 


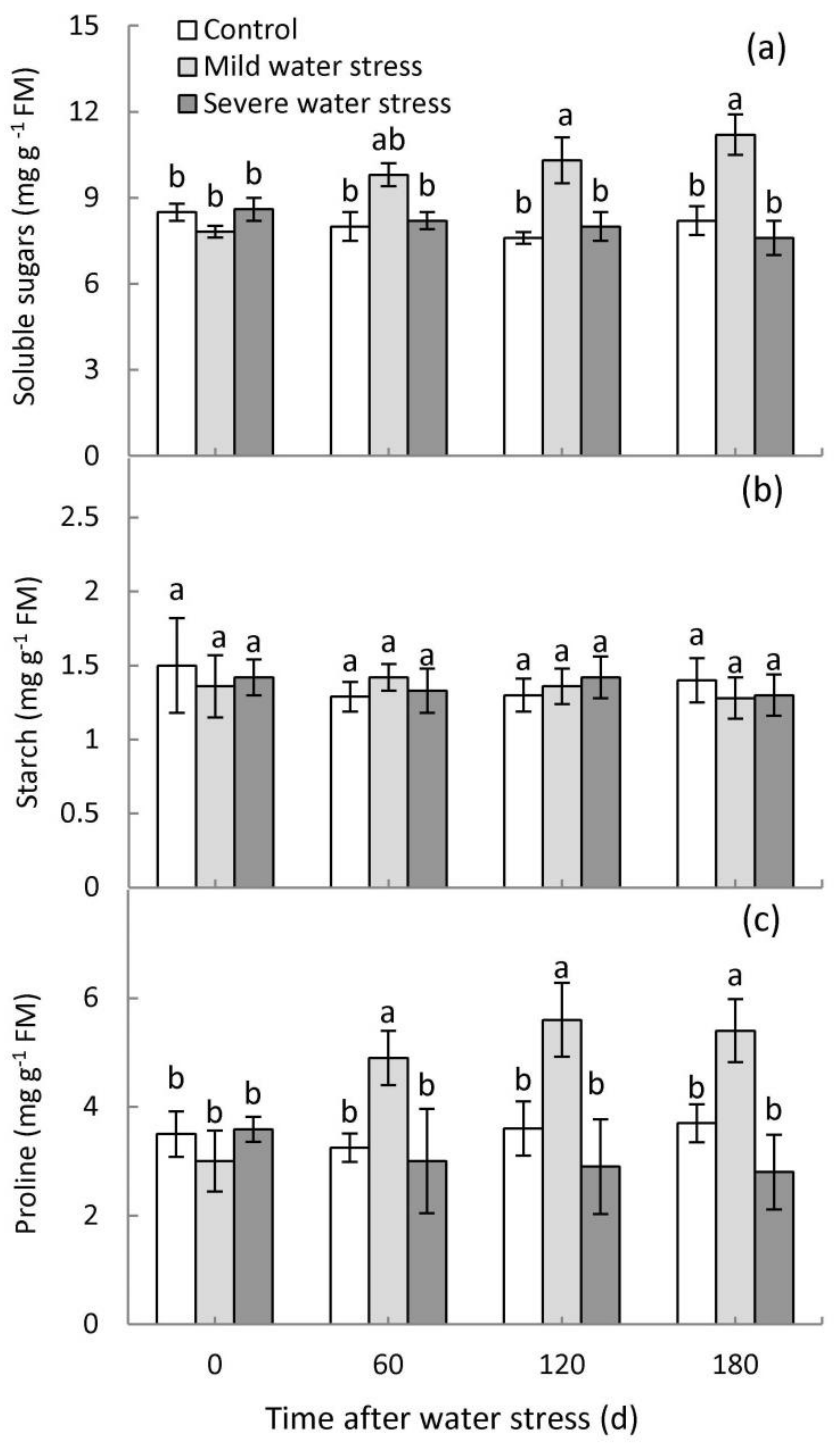

Figure 3: Effects of mild and severe drought stress on the concentration of soluble sugars, starch and proline in Aloe vera plants. Bars indicated with the same letter are not significantly different $(p<0.05$, Tukey test). Values are the mean $\pm \operatorname{SD}(n=4)$.

\subsection{Treatment with mild drought stress enhances photoprotection activity in Aloe leaves ISTT}

Chlorophyll $a$ and $\mathrm{b}$ contents were not affected significantly by various drought levels in Aloe vera plants (Fig. 2). After 120 days treatment, however, carotenoid content of leaves was enhanced only under the mild drought stress (Fig. 2). Under mild drought stress, an increase in carotenoid content can perform an important role as a non-enzymatic antioxidant in the photoprotection of photosynthesis (Miura and Tada, 2014; Habibi and Ajory, 2015) as well as in the dissipation of absorbed light energy as thermal energy (qE) (Cazzonelli and Pogson, 2010). Indeed, when Aloe vera plants were exposed to mild drought stress, the accumulation of protective pigments such as carotenoids in leaves developed an effective photoprotection mechanism, as demonstrated by the maintenance of the maximum quantum yield of photosystem II $\left(\mathrm{F}_{\mathrm{v}} / \mathrm{F}_{\mathrm{m}}\right)$ and photosystem performance index ( $\left.\mathrm{PI}_{\mathrm{abs}}\right)$ in plants treated with mild drought stress (Fig. 3). In contrast, after 120 and 180 days of treatment, $\mathrm{F}_{\mathrm{v}} / \mathrm{F}_{\mathrm{m}}$ and $\mathrm{PI}_{\mathrm{abs}}$ exhibited a significant decrease only in plants subjected to severe drought stress, suggesting a photoinhibitory effect (Diao et al., 2014). Since the shape of the OJIP curve is very sensitive to environmental stress (Strasser et al., 2004), we measured chlorophyll fluorescence to determine the precise effects of drought stress on the photosynthetic 
apparatus ( $\mathrm{Su}$ et al., 2015) using the JIP-test (the analysis of the fluorescence rise OJIP). Under mild drought stress conditions, the OJIP chlorophyll fluorescence curve obtained from the Aloe vera leaves revealed a normal fluorescence rise when compared to control plants (Fig. 4), indicating that reaction centers behave almost normally (Kalaji et al., 2011; Zhang et al., 2014). In this study, however, a quicker fluorescence rise in the $J$ step was perceived in response to severe drought stress, which is related to deactivation of the reaction center leading to drastic reduction in photochemistry through a blockage of electron flow (Strasser et al., 2004; van Heerden et al., 2007; Kalaji et al., 2011).



Figure 2: Effects of mild and severe drought stress on the content of chlorophyll $a, b$ and total carotenoids in Aloe vera plants. Bars indicated with the same letter are not significantly different $(p<0.05$, Tukey test). Values are the mean $\pm \mathrm{SD}(\mathrm{n}=4)$. 
Effects of mild and severe drought stress on the biomass, ... photochemical activity of Aloe vera (L.) Burm.f.

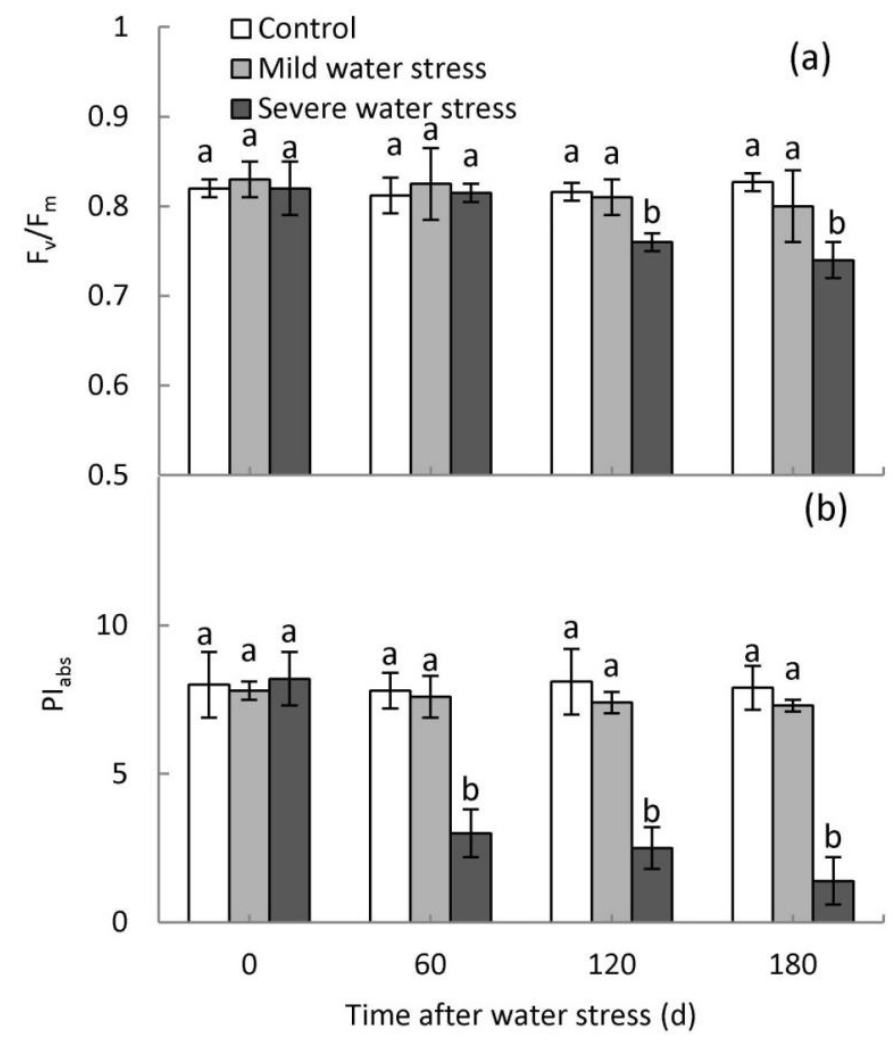

Figure 3: Effects of mild and severe drought stress on the maximum quantum yield of PSII $\left(\mathrm{F}_{\mathrm{v}} / \mathrm{F}_{\mathrm{m}}\right)$ and the Performance Index $\left(\mathrm{PI}_{\mathrm{abs}}\right)$ in Aloe vera plants. Bars indicated with the same letter are not significantly different $(p<$ 0.05 , Tukey test). Values are the mean $\pm \operatorname{SD}(n=4)$.

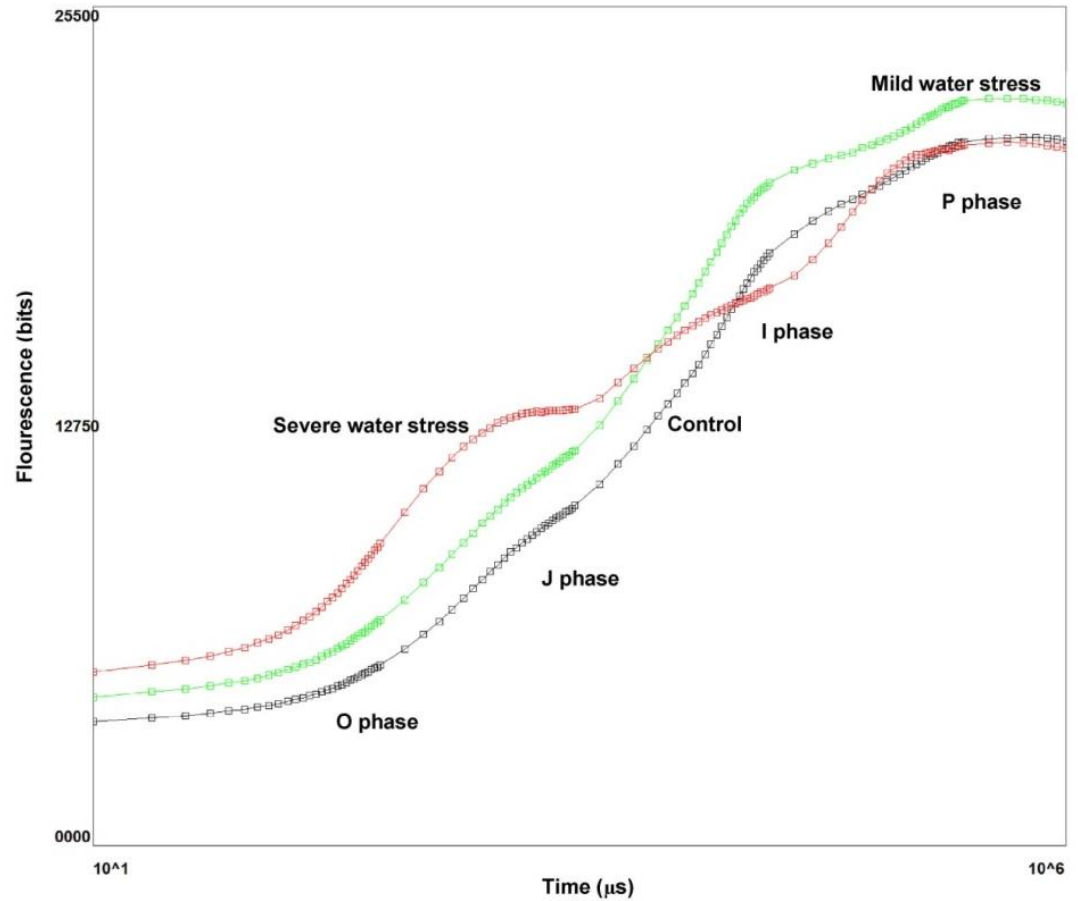

Figure 4: Effects of mild and severe drought stress on the chlorophyll $a$ fluorescence induction curve of Aloe vera plants. Bars indicated with the same letter are not significantly different $(p<0.05$, Tukey test). Values are the mean $\pm \mathrm{SD}(\mathrm{n}=4)$. 


\subsection{Mild drought stress increases phenolic compounds production in Aloe leaves}

Aloe leaves contain remarkably high amounts of phytochemical contents with therapeutic and preventive properties for human beneficial health effects. Phenolic compounds are the second major substances found in Aloe vera, which are used for medicinal purposes (Sathyaprabha et al., 2010; Lopez et al., 2013). Numerous studies have revealed that the quantity of phenolic acids in natural plants was affected by various environmental stresses (Lee et al., 2012; Zhang et al., 2015). In plants treated with drought stress for 180 days, total phenolic and flavonoids was increased under mild drought stress, while their contents remained unchanged under severe drought stress conditions (Fig. 5). After 120 and 180 days of exposure, however, an increase in anthocyanin levels was observed only in plants treated with severe drought stress. These result showed that long-term water loss may be necessary but not sufficient to induce anthocyanin compounds. In our experiments, accumulation of phenolic compounds in treated plants (Fig. 5) was correlated with PAL activation in the aloe leaves (Fig. 6). Under sever dfrought stress PAL activity suppressed, resulting in reduced phenolic compounds in the aloe leaves. Since phenolic compounds accumulation is associated with antioxidant activity (Aladedunye et al., 2008; Zhou et al., 2014; Lee et al., 2017), we investigated antioxidant properties including DPPH radicals in the present research. In more detail, the highest scavenging effect was observed under mild drought stress. As a result, the antioxidant activities of Aloe leaves against DPPH radicals were correlated with higher metabolite contents. In confirmation of this, there was a linear and positive correlation $(\mathrm{r}=0.77, P<0.01)$ between total phenol content and antioxidant activities against DPPH radicals in plants subjected to mild drought stress (Fig. 7). In addition, due to the protective effect of phenolic compounds in the screening of photoradiation (Takahashi and Badger, 2011) as well as their function as a non-enzymatic antioxidant during exposure to drought stress (Quan et al., 2016), this higher phenolic compounds accumulation in plants subjected to mild drought stress, may be an important protection mechanism for photosynthetic primary reactions of Aloe leaves under drought stress. This was corroborated by a linear and positive correlation $(\mathrm{r}=$ $0.73, P<0.01$ ) between total phenol content and $\mathrm{PI}_{\mathrm{abs}}$ in plants subjected to mild drought stress (Fig. 7).



Figure 5: Effects of mild and severe drought stress on the total phenol, flavonoids and anthocyanin content in Aloe vera plants. Bars indicated with the same letter are not significantly different ( $p<0.05$, Tukey test). Values are the mean $\pm \mathrm{SD}(\mathrm{n}=4)$. 
Effects of mild and severe drought stress on the biomass, ... photochemical activity of Aloe vera (L.) Burm.f.

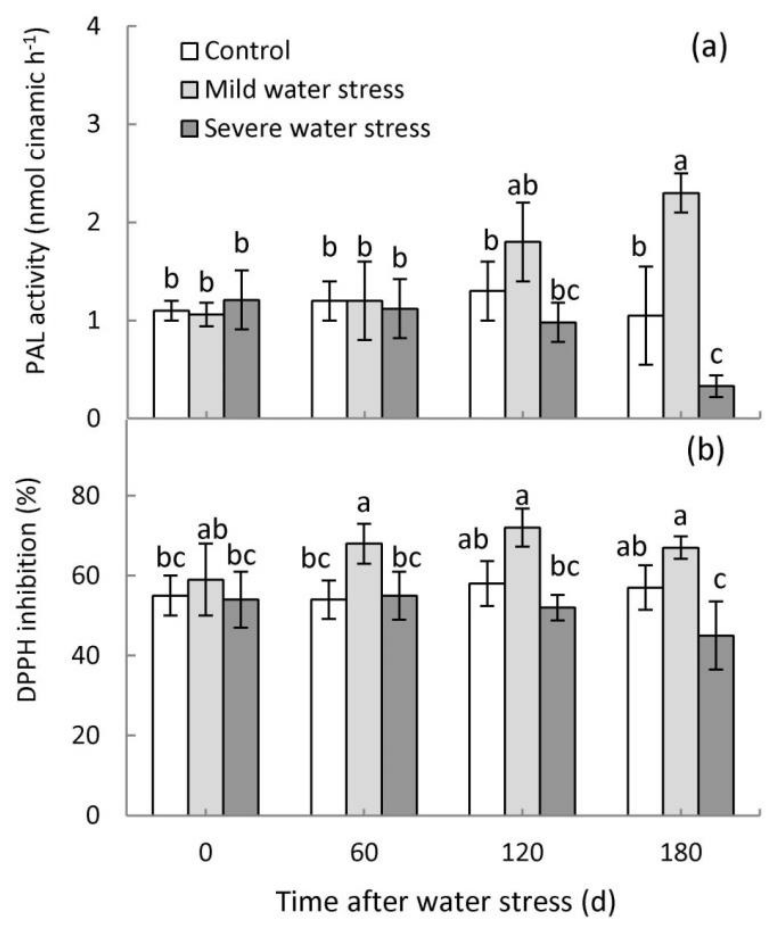

Figure 6. Effects of mild and severe drought stress on the activity of phenylalanine ammonia-lyase (PAL) and the antioxidant activities against DPPH radicals in Aloe vera plants. Bars indicated with the same letter are not significantly different $(p<0.05$, Tukey test). Values are the mean $\pm \operatorname{SD}(\mathrm{n}=4)$.

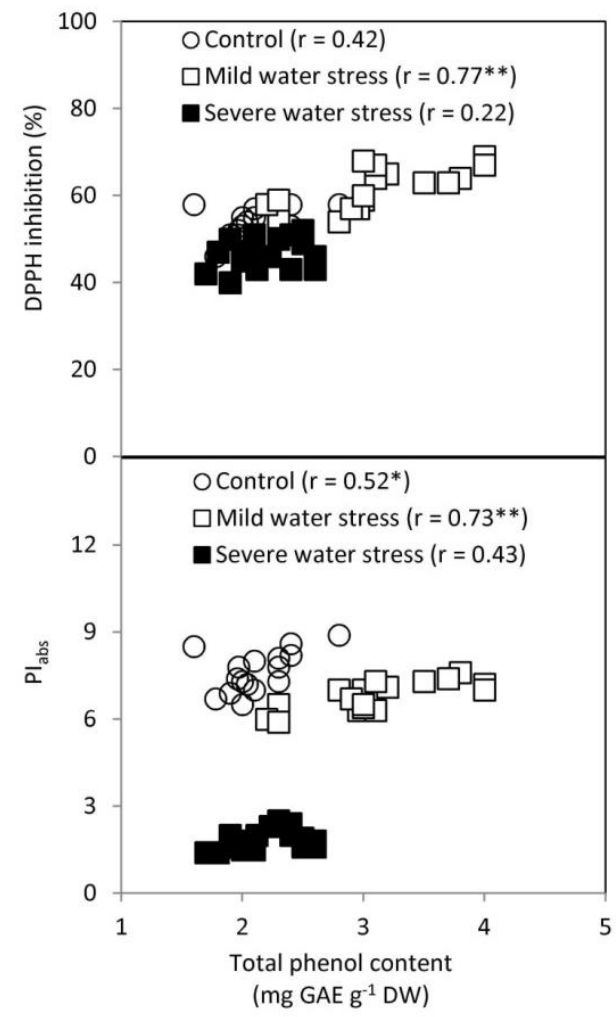

Figure 7: Effects of mild and severe drought stress on the correlation between values of performance index $\left(\mathrm{PI}_{\mathrm{abs}}\right)$ or DPPH inhibition and total phenol content recorded in Aloe vera plants: ns, non-significant, $*$ and $* *$, significant at the $5 \%$ and $1 \%$ levels of probability, respectively. 
Additionally, we assessed the main phenolic acids in the methanol extract of drought-stressed Aloe leaves using HPLC analysis. The typical chromatograms of Aloe leaves are presented in Fig. 8 and 9. The identification of each peak in the sample was performed using the retention time in the chromatogram. Since methanol is an appropriate solvent for the maximum extraction of phenolic compounds (Naczk and Shahidi, 2004), we used this solvent for extraction of phenolic acids in leaves. The quantification of each phenolic acids peak was done using the calibration curves in the range of $0.78-25 \mathrm{ppm}$, and their equations were measured as $\mathrm{y}=$ 130951x-143924 (chlorogenic acid, $\mathrm{r}^{2}=0.992$ ), $\mathrm{y}=$ 97759x-97156 (vanillic acid, $\mathrm{r}^{2}=0.995$ ) and $\mathrm{y}=$ $81796 x-95603$ (rosmarinic acid, $\mathrm{r}^{2}=0.998$ ). This study revealed three major phenolic acid including rosmarinic acid, chlorogenic acid and vanillic acid in leaves. The metabolite profiles exhibited similar patterns except vanillic acid peak. Chlorogenic acid showed little differences with $500 \mu \mathrm{g} \mathrm{g}^{-1}$ (control) and $494 \mu \mathrm{g} \mathrm{g}^{-1}$ (mild drought stress), respectively. Moreover, no significant difference was observed in rosmarinic acid content of leaf among all treatments (control $547 \mu \mathrm{g} \mathrm{g}^{-1}$ and mild drought stress $551 \mu \mathrm{g} \mathrm{g}^{-1}$ ). Under mild drought stress, vanillic acid content was significantly increased in drought-stressed leaves $\left(845 \mu \mathrm{g} \mathrm{g}^{-1}\right)$ as compared with the control leaves $\left(682 \mu \mathrm{g} \mathrm{g}^{-1}\right)$. Vanillic acid and chlorogenic acid are secondary metabolites, which have anti-inflammatory and anti-oxidative and anticancer properties (Chiang et al., 2003; Leal et al., 2011; Gengmao et al., 2015). For this reason, accumulation of vanillic and chlorogenic acid in the Aloe leaves under mild drought stress conditions was measured in this experiment. Here we showed that content of secondary metabolite of vanillic was highest at mild drought stress, suggesting that the level of vanillic acid like other plant secondary metabolites was influenced by the availability of water.

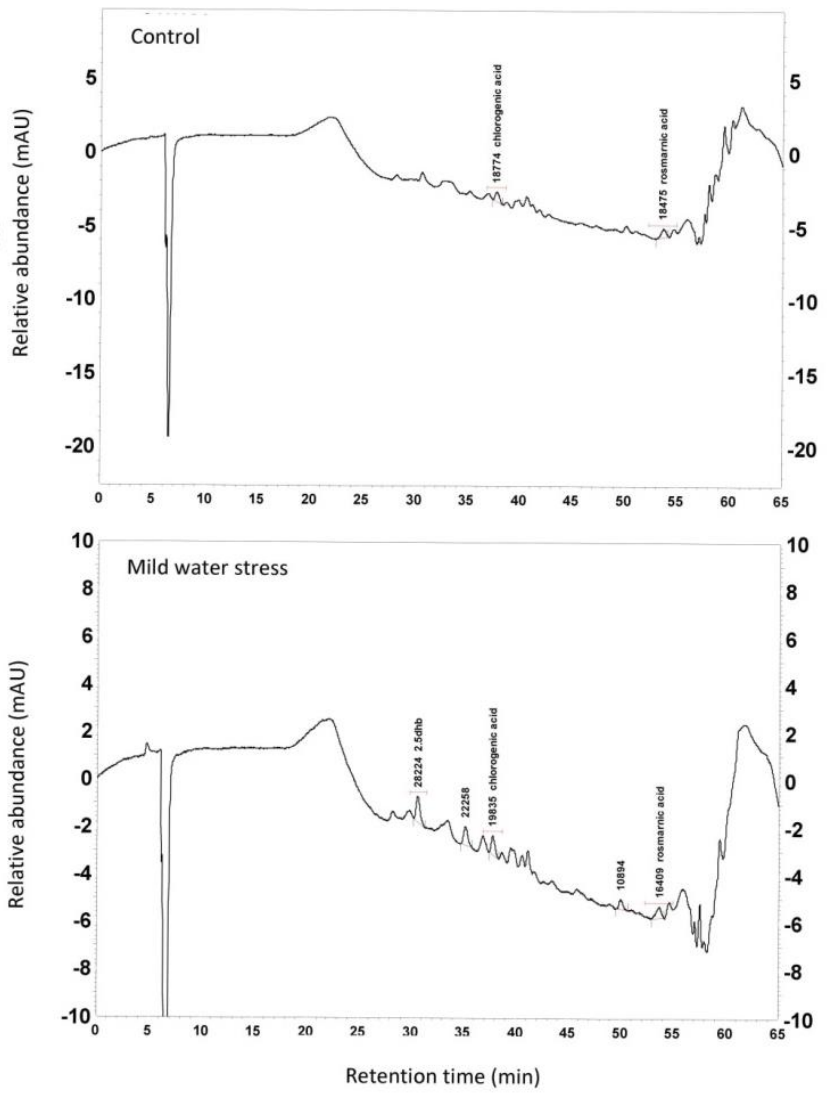

Figure 8: Effects of mild and severe drought stress on the representative chromatogram of prepared extract of Aloe vera leaves for chlorogenic acid and rosmarinic acid measurements. 


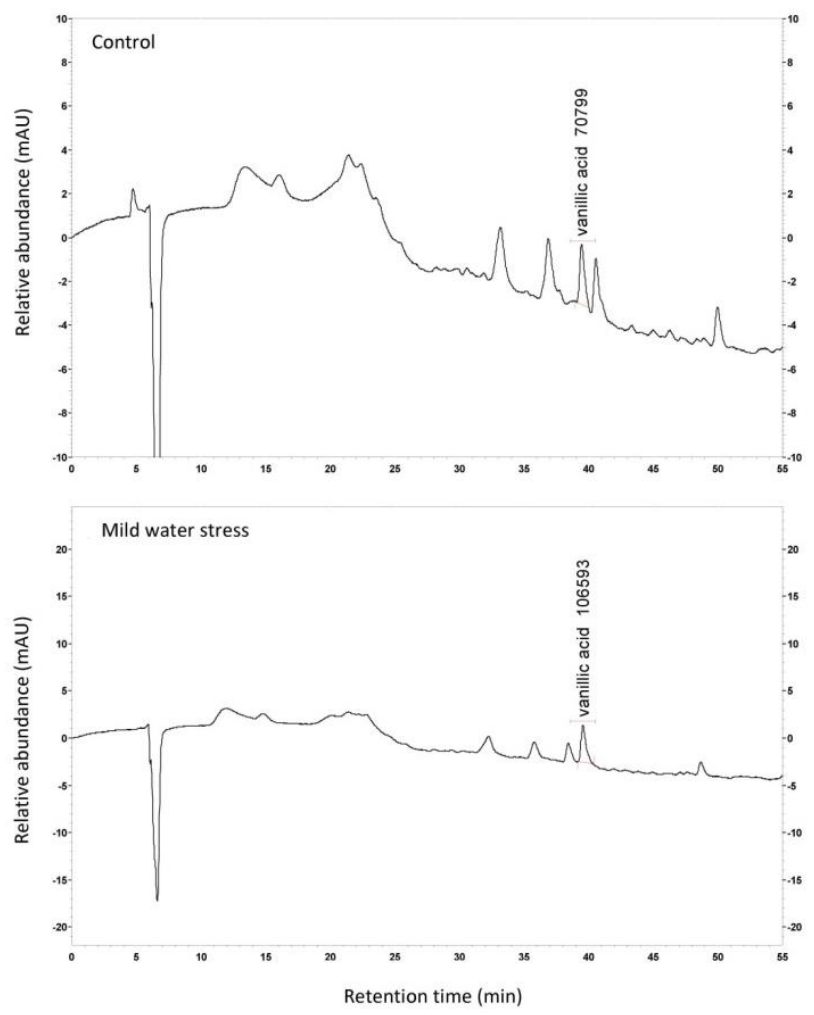

Figure 9: Effects of mild and severe drought stress on the representative chromatogram of prepared extract of Aloe vera leaves for vanillic acid measurement.

\section{CONCLUSION}

After 180 days of exposure, leaf thickness, biomass and gel production were reduced only under severe drfought stress. However, in line with physiological observations, medicinal Aloe plant adapted to mild drought stress during a long-term growth is mainly depended on compatible solutes adjustment, improvement of phenolic compounds production and presence of thick leaves. Mild drought stress improved growth by increasing photosynthesis via enhancing $\mathrm{PI}_{\mathrm{abs}}$. This improvement of PSII activity is coupled with the higher carotenoid and phenol production. In this study, the level of vanillic acid like other plant secondary metabolites was influenced by the availability of water, indicating that fluctuation in the content of vanillic acid was a plant response to environmental factors and part of an adaptative strategy leading to tolerance to abiotic stresses. However, considering conditions of natural habitat, biosynthesis and accumulation of vanillic acid by Aloe leaves in response to mild drought stress is not yet completely clear.

\section{REFERENCES}

Ahmad, P., Jaleel, C. A., Salem, M. A., Nabi, G., Sharma, S. (2010). Roles of enzymatic and nonenzymatic antioxidants in plants during abiotic stress. Critical Reviews in Biotechnology, 30(3), 161-175. doi:10.3109/07388550903524243

Aladedunye, F. A., Okorie, D. A., Ighodaro, O. M. (2008). Anti-inflammatory and antioxidant activities and constituents of Platostoma africanum P. Beauv. Natural Product Research, 22(12), 10671073. doi:10.1080/14786410802264004
Bradford, M. M. (1976). A rapid and sensitive method for the quantitation of microgram quantities of protein utilizing the principle of protein-dye binding. Analytical Biochemistry, 72(1-2), 248254. doi:10.1016/0003-2697(76)90527-3

Bohnert, H. J., Nelson, D. E., Jensen, R. G. (1995). Adaptations to environmental stresses. The Plant Cell, 7(7), 1099. doi:10.1105/tpc.7.7.1099

Cazzonelli, C. I., Pogson, B. J. (2010). Source to sink: regulation of carotenoid biosynthesis in plants.

Acta agriculturae Slovenica, 111 - 1, marec 2018 
Trends in Plant Science, 15, 266-274. doi:10.1016/j.tplants.2010.02.003

Chiang, L.C., Ng, L.T., Chiang, W., Chang, M.Y., Lin, C.C. (2003). Immunomodulatory activities of flavonoids, monoterpenoids, triterpenoids, iridoid glycosides and phenolic compounds of Plantago species. Planta Medica, 69, 600-604. doi:10.1055/s-2003-41113

Cousins, S.R., Witkowski, E.T.F. (2012). African aloe ecology: a review. Journal of Arid Environments, 85, 1-17. doi:10.1016/j.jaridenv.2012.03.022

Delatorre-herrera, J., Delfino, I., Salinas, C., Silva, H., Cardemil, L. (2010). Irrigationrestriction effects on water use efficiency and osmotic adjustment in Aloe vera plants (Aloe barbadensis Miller). Agricultural Water Management, 97, 1564-1570. doi:10.1016/j.agwat.2010.05.008

Diao, M., Ma, L., Wang, J., Cui, J., Fu, A., Liu, H. Y. (2014). Selenium promotes the growth and photosynthesis of tomato seedlings under salt stress by enhancing chloroplast antioxidant defense system. Journal of Plant Growth Regulation, 33(3), 671-682. doi:10.1007/s00344-014-9416-2

Gengmao, Z., Shihui, L., Xing, S., Yizhou, W., Zipan, C. (2015). The role of silicon in physiology of the medicinal plant (Lonicera japonica L.) under salt stress. Scientific Reports, 5, 12696. doi:10.1038/srep12696

Gill, S.S., Tuteja, N. (2010). Reactive oxygen species and antioxidant machinery in abiotic stress tolerance in crop plants. Plant Physiology and Biochemistry, 48, 909-930. doi:10.1016/j.plaphy.2010.08.016

Habibi, G., Hajiboland, R. (2012). Comparison of photosynthesis and antioxidative protection in Sedum album and Sedum stoloniferum (Crassulaceae) under water stress. Photosynthetica, 50, 508-518. doi:10.1007/s11099-012-0066-y

Habibi, G., Ajory, N. (2015). The effect of drought on photosynthetic plasticity in Marrubium vulgare plants growing at low and high altitudes. Journal of Plant Research, 128(6), 987-994. doi:10.1007/s10265-015-0748-1

Habibi, G. (2016). The role of crassulacean acid metabolism induction in plant adaptation to water deficit. In: Water Stress and Crop Plants: A Sustainable Approach, 12-23. doi:10.1002/9781119054450.ch2

Hazrati, S., Tahmasebi-Sarvestani, Z., MokhtassiBidgoli, A., Modarres-Sanavy, S. A. M., Mohammadi, H., Nicola, S. (2017). Effects of zeolite and water stress on growth, yield and chemical compositions of Aloe vera L. Agricultural Water Management, 181, 66-72. doi:10.1016/j.agwat.2016.11.026

Irigoyen, J. J., Einerich, D. W., \& Sánchez-Díaz, M. (1992). Water stress induced changes in concentrations of proline and total soluble sugars in nodulated alfalfa (Medicago sativd) plants. Physiologia plantarum, 84(1), 55-60. doi:10.1111/j.1399-3054.1992.tb08764.x

Jarvis, C. E., \& Walker, J. R. (1993). Simultaneous, rapid, spectrophotometric determination of total starch, amylose and amylopectin. Journal of the Science of Food and Agriculture, 63(1), 53-57. doi:10.1002/jsfa.2740630109

Kalaji, H. M., Bosa, K., Kościelniak, J., ŻukGołaszewska, K. (2011). Effects of salt stress on photosystem II efficiency and $\mathrm{CO}_{2}$ assimilation of two Syrian barley landraces. Environmental and Experimental Botany, 73, 64-72. doi:10.1016/j.envexpbot.2010.10.009

Kooyers, N.J. (2015). The evolution of drought escape and avoidance in natural herbaceous populations. Plant Science, 234, 155-162. doi:10.1016/j.plantsci.2015.02.012

Kranner, I., Minibayeva, F. V., Beckett, R. P., Seal, C. E. (2010). What is stress? Concepts, definitions and applications in seed science. New Phytologist, 188(3), 655-673. doi:10.1111/j.14698137.2010.03461.x

Krizek, D. T., Kramer, G. F., Upadhyaya, A., Mirecki, R. M. (1993). UV-B response of cucumber seedlings grown under metal halide and high pressure sodium/deluxe lamps. Physiologia Plantarum, 88(2), 350-358. doi:10.1111/j.13993054.1993.tb05509.x

Król, A., Amarowicz, R., Weidner, S. (2014). Changes in the composition of phenolic compounds and antioxidant properties of grapevine roots and leaves (Vitis vinifera L.) under continuous of long-term drought stress. Acta Physiologiae Plantarum, 36(6), 1491-1499. doi:10.1007/s11738-014-1526-8

Lee, J. H., Cho, K. M. (2012). Changes occurring in compositional components of black soybeans maintained at room temperature for different storage periods. Food Chemistry, 131(1), 161-169. doi:10.1016/j.foodchem.2011.08.052

Leal, L.K.A.M., Pierdoná, T.M., Góes, J.G.S., Fonsêca, K.S., Canuto, K.M., Silveira, E.R., Bezerra, A.M.E., Viana, G.S.B. (2011). A comparative chemical and pharmacological study of standardized extracts and vanillic acid from wild and cultivated Amburana cearensis AC Smith. 
Effects of mild and severe drought stress on the biomass, ... photochemical activity of Aloe vera (L.) Burm.f.

Phytomedicine, $\quad$ 18(2-3), doi:10.1016/j.phymed.2010.05.012

Lee, Y. H., Kim, B., Kim, S., Kim, M. S., Kim, H., Hwang, S. R., Lee, J. H. (2017). Characterization of metabolite profiles from the leaves of green perilla (Perilla frutescens) by ultra-high performance liquid chromatography coupled with electrospray ionization quadrupole time-of-flight mass spectrometry and screening for their antioxidant properties. Journal of Food and Drug Analysis, 25(4), 776-788. doi:10.1016/j.jfda.2016.09.003

Lichtenthaler, H.K., Wellburn, A.R. (1983). Determinations of total carotenoids and chlorophylls $a$ and $b$ of leaf extracts in different solvents. Biochemical Society Transactions, 591592. doi:10.1042/bst0110591

Lopez, A., de Tangil, M. S., Orellana, O. V., Ramirez, A. S., Rico, M. (2013). Phenolic constituents, antioxidant and preliminary anti-mycoplasmic activities of leaf skin and flowers of Aloe vera. Molecules, $\quad 18, \quad$ 4942-4954. doi:10.3390/molecules 18054942

Lucini, L., Pellizzoni, M., Molinari, G. Pietro, (2013). Anthraquinones and polysaccharides content and distribution in Aloe plants grown under different light intensities. Biochemical Systematics and Ecology, 51, 264-268. doi:10.1016/j.bse.2013.09.007

Quan, N.T., Anh, L.H., Khang, D.T., Tuyen, P.T., Toan, N.P., Minh, T.N., Bach, D.T., Ha, P.T.T., Elzaawely, A.A., Khanh, T.D., Trung, K.H. (2016). Involvement of secondary metabolites in response to drought stress of rice (Oryza sativa L.). Agriculture, $\quad 6(2), \quad 23$. doi:10.3390/agriculture6020023

Ma, D., Sun, D., Wang, C., Li, Y., Guo, T. (2014). Expression of flavonoid biosynthesis genes and accumulation of flavonoid in wheat leaves in response to drought stress. Plant Physiology and Biochemistry, $\quad 80, \quad 60-66$. doi:10.1016/j.plaphy.2014.03.024

Meda, A., Lamien, C. E., Romito, M., Millogo, J., Nacoulma, O. G. (2005). Determination of the total phenolic, flavonoid and proline contents in Burkina Fasan honey, as well as their radical scavenging activity. Food Chemistry, 91(3), 571-577. doi:10.1016/j.foodchem.2004.10.006

Mittler, R., Vanderauwera, S., Suzuki, N., Miller, G., Tognetti, V.B., Vandepoele, K., Gollery, M., Shulaev, V., Van Breusegem, F. (2011). ROS signaling: the new wave? Trends in Plant Science, 16, 300-309. doi:10.1016/j.tplants.2011.03.007
Miura, K., Tada, Y. (2014). Regulation of water, salinity, and cold stress responses by salicylic acid. Frontiers in Plant Science, 5, 4-12. doi:10.3389/fpls.2014.00004

Naczk, M., Shahidi, F. (2004). Extraction and analysis of phenolic in food. Journal of Chromatography A, 1054, 95-111. doi:10.1016/S0021-9673(04)014098

Ray, A., Dutta Gupta, S., Ghosh, S., Aswatha, S.M., Kabi, B. (2013). Chemometricstudies on mineral distribution and microstructure analysis of freezedried Aloe vera L. gel at different harvesting regimens. Industrial Crops and Products, 51, 194201. doi:10.1016/j.indcrop.2013.08.080

Salinas, C., Handford, M., Pauly, M., Dupree, P., Cardemil, L. (2016). Structural modifications of fructans in Aloe barbadensis Miller (Aloe vera) grown under water stress. PloS One, 11(7), e0159819. doi:10.1371/journal.pone.0159819

Sankar, B., Jaleel, C.A., Manivannan, P., Kishorekumar, A., Somasundaram, R., Panneerselvam, R. (2007). Drought-induced biochemical modifications and proline metabolism in Abelmoschus esculentus (L.) Moench. Acta Botanica Croatica, 66(1), 43-56.

Sathyaprabha, G., Kumaravel, S., Ruffina, D., Praveenkumar, P. A. (2010). comparative study on antioxidant, proximate analysis, antimicrobial activity and phytochemical analysis of Aloe vera and Cissus quadrangularis by GC-MS. Journal of Pharmacy Research, 3, 2970-2973.

Silva, H., Sagardia, S., Seguel, O., Torres, C., Tapia, C., Franck, N., Cardemil, L. (2010). Effect of water availability on growth and water use efficiency for biomass and gel production in Aloe vera (Aloe barbadensis M.). Industrial Crops and Products, 31(1), 20-27. doi:10.1016/j.indcrop.2009.08.001

Silva, H., Sagardia, S., Ortiz, M., Franck, N., Opazo, M., Quiroz, M., Baginsky, C., Tapia, C. (2014). Relationships between leaf anatomy, morphology, and water useefficiency in Aloe vera (L) Burm as a function of water availability. Revista Chilena de Historia Natural, 87 (13), 1-10.

Strasser, R. J., Tsimilli-Michael, M., Srivastava, A. (2004). Analysis of the chlorophyll $a$ fluorescence transient. In: Chlorophyll a fluorescence. Springer Netherlands 321-362. doi:10.1007/978-1-40203218-9_12

Su, L., Dai, Z., Li, S., Xin, H. (2015). A novel system for evaluating drought-cold tolerance of grapevines using chlorophyll fluorescence. BMC Plant Biology, 11, 82. doi:10.1186/s12870-015-0459-8 
Takahashi, S. Badger, M.R. (2011). Photoprotection in plants: a new light on photosystem II damage. Trends in Plant Science, 31, 53-60. doi:10.1016/j.tplants.2010.10.001

Van Heerden, P. D. R., Swanepoel, J. W., Krüger, G. H. J. (2007). Modulation of photosynthesis by drought in two desert scrub species exhibiting $\mathrm{C}_{3}$-mode $\mathrm{CO}_{2}$ assimilation. Environmental and Experimental Botany, 61(2), 124-136. doi:10.1016/j.envexpbot.2007.05.005

Velikova, V., Yordanov, I., Edreva, A. (2000). Oxidative stress and some antioxidant systems in acid rain-treated bean plants: protective role of exogenous polyamines. Plant Science, 151(1), 5966. doi:10.1016/S0168-9452(99)00197-1

Velioglu, Y. S., Mazza, G., Gao, L., Oomah, B. D. (1998). Antioxidant activity and total phenolics in selected fruits, vegetables, and grain products. Journal of Agricultural and Food Chemistry, 46(10), 4113-4117. doi:10.1021/jf9801973

Weidner, S., Karolak, M., Karamac, M., Kosinska, A., Amarowicz, R. (2009). Phenolic compounds and properties of antioxidants in grapevine roots (Vitis vinifera L.) under drought stress followed by recovery. Acta Societatis Botanicorum Poloniae, 78(2), 97-103. doi:10.5586/asbp.2009.013

Wu, Z. Z., Ying, Y. Q., Zhang, Y. B., Bi, Y. F., Wang, A. K.,Du, X. H. (2018). Alleviation of drought stress in Phyllostachys edulis by $\mathrm{N}$ and $\mathrm{P}$ application. Scientific Reports, 8(1), 228. doi:10.1038/s41598-017-18609-y

Yen, G. C., Chen, H. Y. (1995). Antioxidant activity of various tea extracts in relation to their antimutagenicity. Journal of Agricultural and Food Chemistry, 43(1), 27-32. doi:10.1021/jf00049a007

Zhang, G., Liu, Y., Ni, Y., Meng, Z., Lu, T., Li, T. (2014). Exogenous calcium alleviates low night temperature stress on the photosynthetic apparatus of tomato leaves. PloS One, 9(5), e97322. doi:10.1371/journal.pone.0097322

Zhang, B., Deng, Z., Ramdath, D. D., Tang, Y., Chen, P. X., Liu, R, Tsao, R. (2015). Phenolic profiles of 20 Canadian lentil cultivars and their contribution to antioxidant activity and inhibitory effects on $\alpha$ glucosidase and pancreatic lipase. Food Chemistry, 172 , 862-872. doi:10.1016/j.foodchem.2014.09.144

Zhou, X. J., Yan, L. L., Yin, P. P., Shi, L. L., Zhang, J. H., Liu, Y. J., Ma, C. (2014). Structural characterisation and antioxidant activity evaluation of phenolic compounds from cold-pressed Perilla frutescens var. arguta seed flour. Food chemistry, 164 , 150-157. doi:10.1016/j.foodchem.2014.05.062

Zucker, M. (1965). Induction of phenylalanine deaminase by light and its relation to chlorogenic acid synthesis in potato tuber tissue. Plant Physiology, 40, 779. doi:10.1104/pp.40.5.779 